\title{
Reversible Focal Radiological Changes due to Non-Convulsive Status Epilepticus of the Right Parietooccipital Lobe
}

\author{
Să̆ Parietooksipital Lobun Nonkonvïlsif Status Epileptikusu Nedeniyle \\ Reversibl Fokal Radyolojik Değişiklikler
}

\author{
Nhat Nguyen TUAN HUYNH ${ }^{1}$, Akutsu HIROYOSHI ${ }^{1}$, Noguchi SHOZO ${ }^{2}$, Tsunoda TAKASHI ${ }^{2}$, \\ Tsurushima HIDEO ${ }^{1}$, Matsumura AKIRA $^{1}$ \\ ${ }^{1}$ University of Tsukuba, Graduate School of Comprehensive Human Science, Department of Neurosurgery, Tsukuba, Japan \\ 2Ibaraki Central Hospital, Department of Neurosurgery, Kasama, Japan \\ ${ }^{3}$ Cho Ray Hospital, Department of Radiology, Ho Chi Minh, Viet Nam
}

Correspondence address: Tsurushima HIDEO / E-mail: hideo-tsurushima@md.tsukuba.ac.jp

\begin{abstract}
We describe a 62-year-old woman suffering from visual hallucination due to focal status epilepticus investigated by means of Magnetic Resonance Imaging (MRI), Magnetic Resonance Angiography (MRA), Electroencephalography (EEG), and 99m Technetium ethylcysteinate dimer Single Photon Emission Computed Tomography (Tc-99m ECD SPECT). EEG showed spikes in the right parietooccipital area. MRI demonstrated gyral swelling and signal hyperintensity in the right parietooccipital cortex with effacement of adjacent cortical sulci on T2weighted and Fluid Attenuation Inversion Recovery (FLAIR) images. MRA indicated localized dilation of the right posterior cerebral artery (PCA) and parietal branch of the right middle cerebral artery (MCA), corresponding to the epileptic area shown on EEG. Hyperperfusion in the right parietooccipital lobe was observed by Tc-99m ECD SPECT. All these findings completely resolved on the follow-up studies 2 months later. We present the case showing the transient radiological alterations on MRA corresponding to the epileptic area.
\end{abstract}

KEYWORDS: Status epilepticus, Reversible MRI, SPECT, MRA, Hyperperfusion

öz

Fokal status epileptikus nedeniyle görsel halüsinasyonları olan ve Manyetik Rezonans Görüntüleme (MRG), Manyetik Rezonans Anjiyografi (MRA), Elektroensefalografi (EEG) ve 99 m Teknesyum etilsisteinat dimer Tek Foton Emisyonu Bilgisayarlı Tomografi (Tc-99m ECD SPECT) ile incelenen 62 yaşında bir kadını sunuyoruz. EEG sağ parietooksipital bölgede dikenler gösterdi. MRG sağ parietooksipital kortekste girus şişmesi ve sinyal hiperintensitesiyle birlikte T2 ağırlıklı ve Sıvı Atenüasyonu İnversiyon Geri Kazanımı (FLAIR) görüntülerinde komşu kortikal sulkuslarda silinme gösterdi. MRA EEG'de gösterilen epileptik bölgeye karşılık gelecek şekilde sağ orta serebral arter (MCA) parietal dalı ve sağ posterior serebral arter (PCA) lokalize dilatasyonuna işaret etti. Tc-99m ECD SPECT ile sağ parietooksipital lobda hiperperfüzyon görüldü. Tüm bu bulgular 2 ay sonraki takip çalışmalarında tamamen geçmişti. Epileptik bölgeye karşılık gelen geçici MRA radyolojik değişiklikleri gösteren vakayı sunuyoruz.

ANAHTAR SÖZCÜKLER: Status epileptikus, ReversibI MRG, SPECT, MRA, Hiperperfüzyon

\section{INTRODUCTION}

There are some reports of reversible Magnetic Resonance Imaging (MRI) abnormalities following status epilepticus (7-9). The present case suffered from non-convulsive status epilepticus and was followed up within 2 months using EEG, MRI, Magnetic Resonance Angiography (MRA) and 99m-Technetium ethylcysteinate dimer Single Photon Emission Computed Tomography (Tc-99m ECD SPECT). There are few reports of MRA abnormalities following status epilepticus (3). We want to indicate the possibility of reversible radiological alterations in MRA, due to status epilepticus.

\section{CASE REPORT}

A 62-year-old woman had mild mental retardation from childhood. She was diagnosed with epilepsy (unclear category) in childhood. Under medication with Phenytoin $300 \mathrm{mg} /$ day and Zonisamide $400 \mathrm{mg} /$ day, her seizures have been well controlled. Two years earlier, she complained of visual hallucination, such as "Fireballs are flying toward me", occasionally associated with temporary loss of consciousness.

On admission, she complained of periodically photic discharge on the left visual field and severe visual field defect on the left, and developed a generalized tonic clonic seizure. EEG showed spiky waves in the right parietooccipital area. MRI 
on the admission day (on day 1) demonstrated gyral swelling and increased signal intensity on T2-weighted and fluid attenuation inversion recovery (FLAIR) images in the right parietooccipital lobe with cortical sulcal effacement (Figure $1 A, B)$. MRA on day 1 showed localized dilation of the right posterior cerebral artery (PCA) and the parietal branch of the right middle cerebral artery (Figure $2 \mathrm{~A}, \mathrm{C}$ ). Tc-99m ECD SPECT on day 1 indicated a right parietooccipital hyperperfusion (Figure 3A).

Phenytoin was increased up to $375 \mathrm{mg} /$ day, and the seizure subsided gradually thereafter. The decrease in photic discharge and improvement of visual field defects were observed, and EEG showed the disappearance of spiky waves 2 weeks later. Follow-up MRI indicated partial regression of the right parietooccipital signal intensity in 2 weeks, along with complete normalization of the signal intensity in 2 months (Figure 1D). The caliber of the right PCA and the parietal branch of the right MCA returned gradually to the normal range on MRA 2 weeks later (Figure 2D) and 2 months later (Figure 2 B,E). Tc-99m ECD SPECT was normalized in 2 months (Figure 3B).

\section{DISCUSSION}

Inthepresentcase,MRIshowed temporarysignalhyperintensity of the right parietooccipital cortex on T2-weighted and FLAIR images along with contrast enhancement on T1-weighted images after gadolinium administration. Additionally, Tc-99m ECD SPECT indicated a right parietooccipital hyperperfusion, corresponding anatomically to the epileptic area displayed on EEG. All the findings completely resolved upon follow-up 2 months later. Although similar findings have been reported in recent years $(1,3,5,7,8)$, there are few reports referring to the MRA findings due to the status epilepticus (2). We want to indicate the reversible radiological alterations in MRA.

Transient radiological findings in most cases of status epilepticus were considered to be due to vasogenic cerebral edema (4). Another report indicated that a prolonged status epilepticus could lead to cytotoxic cerebral edema (6). The
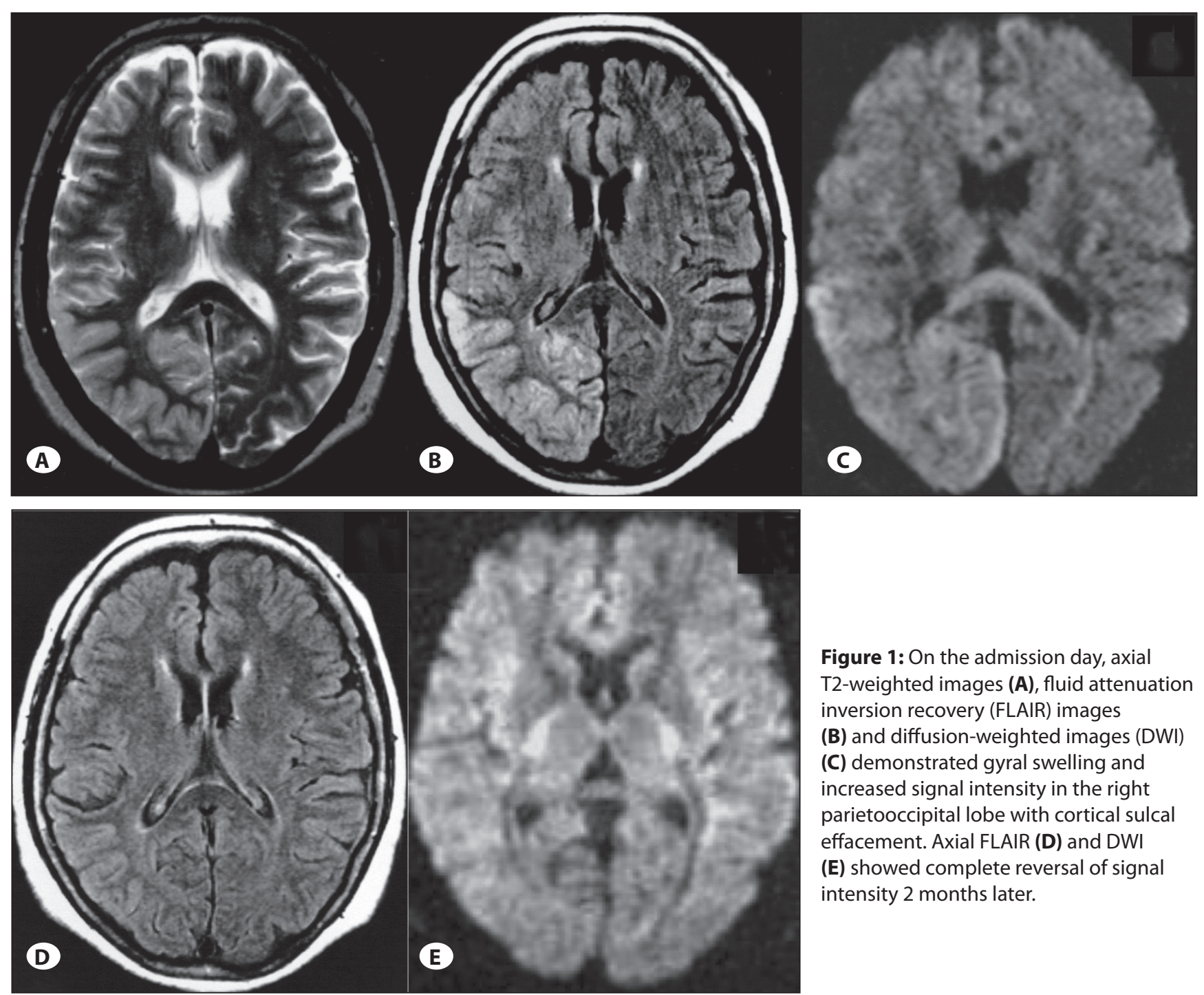

Figure 1: On the admission day, axial T2-weighted images (A), fluid attenuation inversion recovery (FLAIR) images (B) and diffusion-weighted images (DWI) (C) demonstrated gyral swelling and increased signal intensity in the right parietooccipital lobe with cortical sulcal effacement. Axial FLAIR (D) and DWI (E) showed complete reversal of signal intensity 2 months later. 

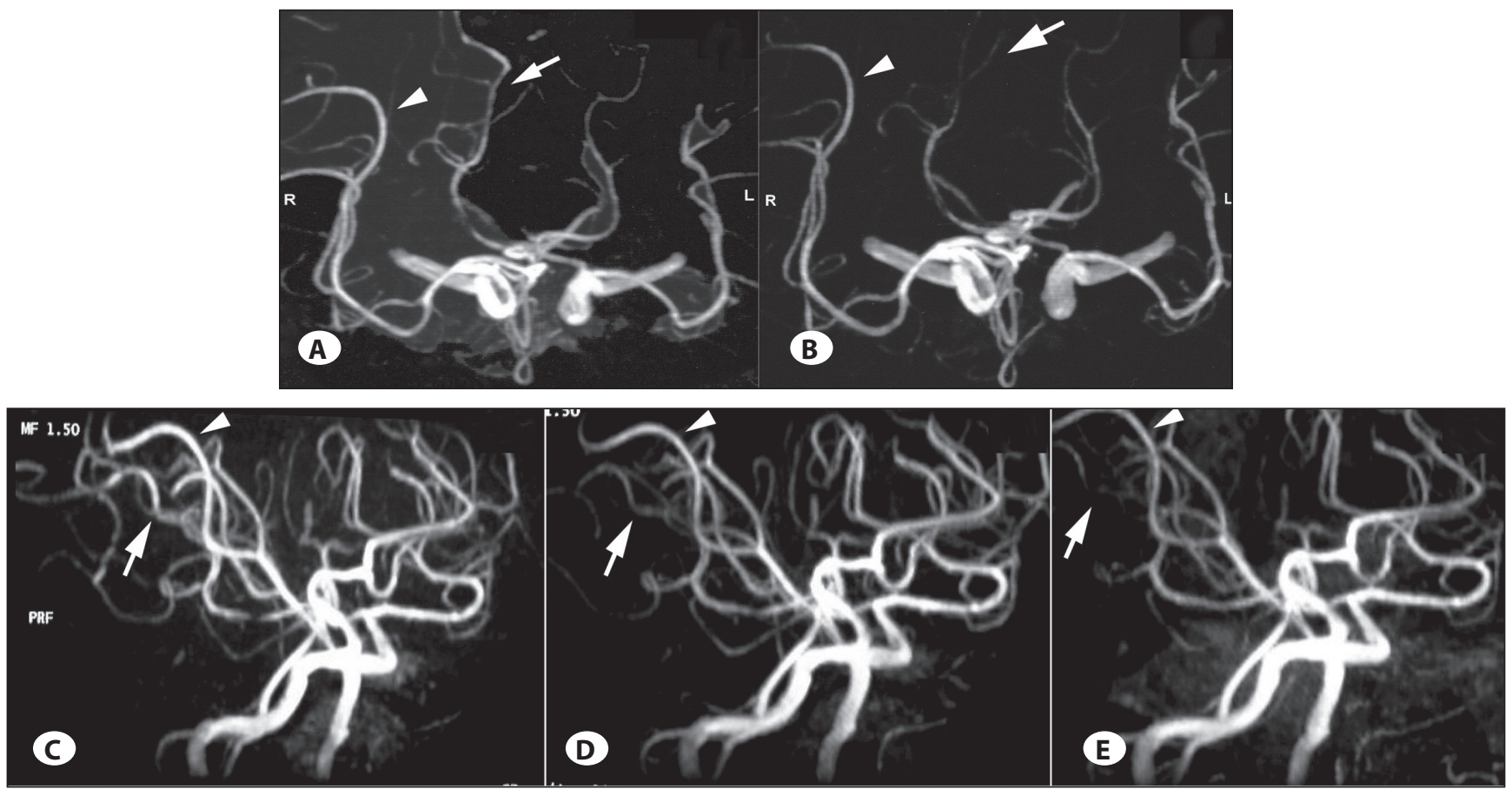

Figure 2: Anteroposterior view of Magnetic Resonance Angiography (MRA) on day 1 (A) showed localized dilation of right posterior cerebral artery (PCA) and the parietal branch of the right middle cerebral artery (MCA). Anteroposterior view of MRA (B) showed that the caliber of the right PCA and the parietal branch of MCA almost returned to normal ranges 2 months later. Right oblique views of MRA performed at day 1 (C), 2 weeks (D), and 2 months (E) demonstrate gradual normalization of the vessel caliber. The arrowheads indicate MCA, and the arrows indicate PCA.
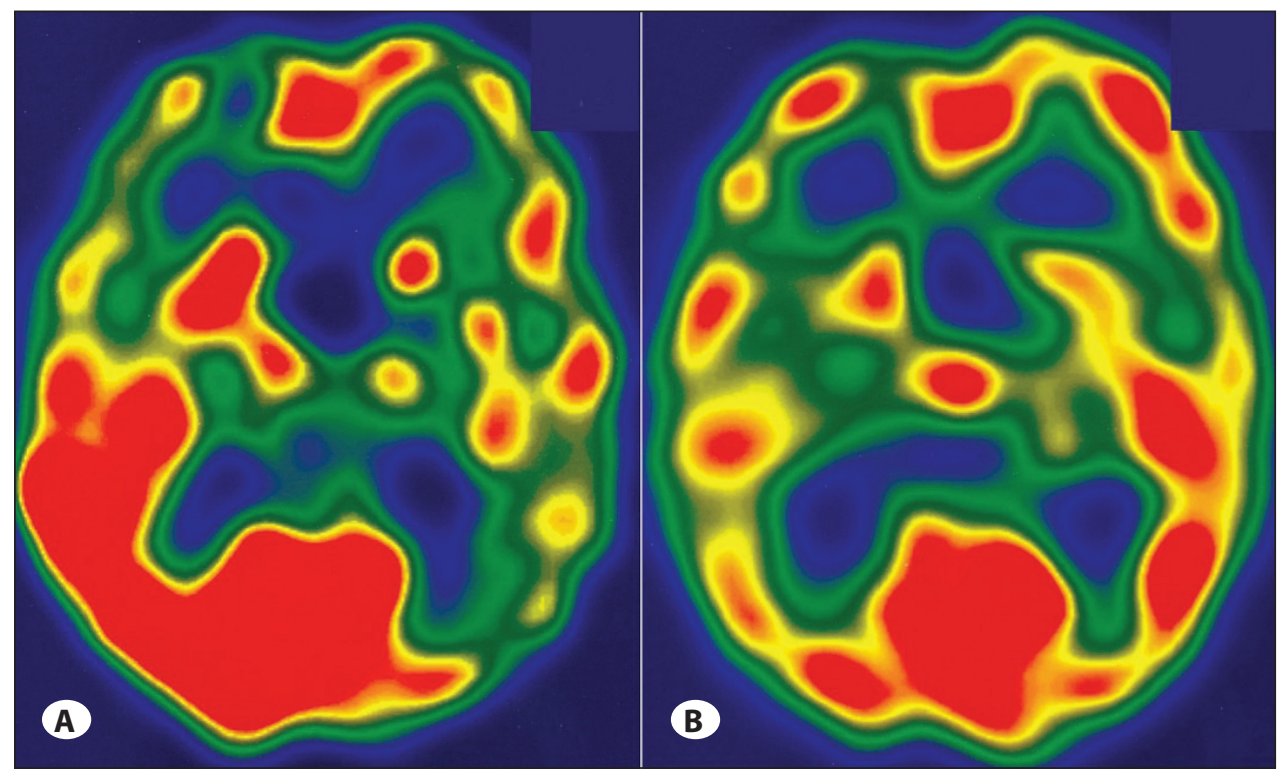

Figure 3: 99m-Technetium ethylcysteinate dimer Single Photon Emission Computed Tomography (Tc-99m ECD SPECT) indicated a right parietooccipital hyperperfusion on the admission day (A), and normal perfusion in 2 months (B).

cytotoxic edema is caused by an abrupt increase in blood pressure and subsequent cerebral vasoconstriction leading to cerebral ischemia $(2,4)$. The second type arises due to an increase in blood pressure mediated by the cerebral autoregulation, causing dilation of cerebral vasculature and vasogenic cerebral edema (4). In the present case, follow-up MRI demonstrated complete reversal of signal abnormalities, confirming reversible vasogenic edema, due to the fact that cytotoxic edema formation causes irreversible hyperintensity changes and subsequently leads to permanent cerebral damage $(10,11)$. In our patient, the underlying pathophysiological mechanism is thought to be due to vasogenic cerebral edema. 


\section{REFERENCES}

1. Bauer J, Stefan H, Huk WJ, Feistel H, Hilz MJ, Brinkmann HG, Druschky KF, Neundorfer B: CT, MRI and SPECT neuroimaging in status epilepticus with simple partial and complex partial seizures: Case report. J Neurol 236:296-299, 1989

2. Casey SO, Sampaio RC, Michel E, Truwit CL: Posterior reversible encephalopathy syndrome: Utility of fluid-attenuated inversion recovery MR; Imaging in the detection of cortical and subcortical lesions. Am J Neuroradiol 21:1 199-1206, 2000

3. Cole AJ: Status epilepticus and periictal imaging. Epilepsia 45:72-77, 2004

4. Garg RK: Posterior leukoencephalopathy syndrome. Postgrad Med 77:24-28, 2001

5. Henry TR, Drury I, Brunberg JA, Pennell PB, Mckeever PE, Beydoun A: Focal cerebral magnetic resonance changes associated with partial status epilepticus. Epilepsia 35:35-41, 1994

6. Hisano T, Ohno M, Egawa T, Takano T, Shimada M: Changes in diffusion-weighted MRI after status epilepticus. Pediatr Neurol 22:327-329, 2000
7. Huang YC, Weng HH, Tsai YT, Huang YC, Hsiao MC, Wu CY, Lin $\mathrm{YH}, \mathrm{Hsu} \mathrm{HL}$, Lee JD: Periictal magnetic resonance imaging in status epilepticus. Epilepsy Res 86:72-81, 2009

8. Juhász C, Scheidl E, Szirmai I: Reversible focal MRI abnormalities due to status epilepticus. An EEG, single photon emission computed tomography, transcranial Doppler follow-up study. Electroencephalogr Clin Neurophysiol 107:402-407, 1998

9. Milligan TA, Zamani A, Bromfield E: Frequency and patterns of MRI abnormalities due to status epilepticus. Seizure 18: 104-108, 2009

10. Schaefer PW, Buonanno FS, Gonzalez RG, Schwamm LH: Diffusion-weighted imaging discriminates between cytotoxic and vasogenic edema in a patient with eclampsia. Stroke 28 : 1082-1085, 1997

11. Stott VL, Hurrell MA, Anderson TJ: Reversible posterior leukoencephalopathy syndrome: A misnomer reviewed. Intern Med J 35: 2005 